\title{
LAPSEN ELATUS, VANHEMPIEN TOIMEENTULO JA KÖYHYYS
}

Mari Haapanen: VTK, tutkimusavustaja, Turun yliopisto

Mia Hakovirta: VTT, akatemiatutkija, Turun yliopisto

maanhaa@utu.fi;miabak@utu.fi

Janus vol. 27 (4) 2019, 395-412

(U)

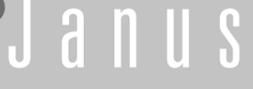

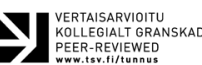

Tiivistelmä

Artikkelissa tutkimme köyhyys- ja hyvinvointitutkimuksen viitekehyksessä lapsen elatusta, kun lapsen vanhemmat asuvat erillään. Tarkastelemme, muodostuuko lapsen saama elatus toisen vanhemman maksamasta elatusavusta vai yhteiskunnan takaamasta elatustuesta, ja onko eri tuloluokkien välillä eroja elatuksen muodoissa. Tutkimme myös, mikä vaikutus lapsen elatuksella on vanhempien toimeentuloon ja köyhyyteen. Aineistona käytimme Suomen tulonjakotilaston palveluaineistoa vuodelta 2013. Tulosten mukaan suurempituloiset yksinhuoltajaäidit saivat useammin elatusapua lapsen isältä ja pienituloiset yksinhuoltajaäidit elatustukea. Pienituloisilla isillä elatusapu muodosti suuremman osuuden tuloista kuin suurempituloisissa kotitalouksissa. Köyhyystarkastelu osoitti, että elatusapu vähentää köyhyyttä yksinhuoltajaäitien kotitalouksissa elatustukea enemmän. Elatusavun maksaminen taas lisäsi köyhyyttä etenkin yksinasuvien isien kotitalouksissa. Elatusjärjestelmän toimivuutta tulisikin jatkossa arvioida erityisesti pienituloisten vanhempien näkökulmasta.

\section{JOHDANTO}

Perhesuhteet eivät aina sijoitu perheen yhteiseen kotiin vaan yhä suurempi osa lapsista elää lapsuuttaan erossa toisesta vanhemmastaan. Tämä nostaa esiin kysymyksen siitä, kuinka lapsen elatus toteutuu eron jälkeisissä perhesuhteissa. Vanhemmuussuhteiden uudelleenjärjestely eron jälkeen nojaa periaatteellisesti lapsen oikeuteen saada elatusta myös siltä vanhemmalta, jonka kanssa hän asu. Vanhemman näkökulmasta on kyse molempien vanhempien lakisääteisestä velvollisuudesta huolehtia lapsen elatuksesta. Lapsen elatuksen kysymykset kietoutuvatkin monimutkaisella tavalla vanhemmuuteen, lasten oikeuksiin ja vanhempien välisiin vel- vollisuuksiin lapsen taloudellisesta huolenpidosta.

Useiden tutkimusten mukaan ero on taloudellinen riski perheiden toimeentulolle, sillä samoilla tuloilla joudutaan elättämään kaksi kotitaloutta (Airio 2010; Uunk 2004; Mortelmans \& Deferver 2017). Lapsiköyhyys kohdistuu usein yksinhuoltajakotitalouksiin (Karvonen \& Salmi 2016), jotka ovat pääasiassa äidin ja lapsen muodostamia perheitä (SVT 2019). Yksinhuoltajakotitalouksien toimeentuloriskiä voi kuitenkin lieventää se, jos isät jakavat elatusvastuuta lapsista (Stirling \& Aldrich 2008) esimerkiksi maksamalla elatusapua. Elatusavulla tarkoitetaan tyypillisesti säännöllistä rahallista maksusuo- 
ritusta, jolla lapsen toinen vanhempi osallistuu toisessa kotitaloudessa asuvan lapsen taloudelliseen huolenpitoon (Skinner ym. 2007).

Elatusjärjestelmällä turvataan se, että lapsi saa riittävää taloudellista huolenpitoa molemmilta vanhemmiltaan ja elatusjärjestelmä voi siten potentiaalisesti parantaa lasten toimeentuloa (Skinner \& Davidson 2009). Kansainväliset vertailut osoittavat elatusjärjestelmän vähentävän lapsiköyhyyttä yksinhuoltajaperheissä (Skinner ym. 2007; Hakovirta 2011). Maiden elatusjärjestelmät eroavat kuitenkin siinä, miten yhteiskunta on ottanut vastuulleen lapsen elatukseen liittyviä tehtäviä (Corden 1999; Miller 1996). Useissa maissa lapsen elatus on täysin riippuvainen toisen vanhemman maksamasta elatusavusta, kun taas Pohjoismaiden ja muutamien Keski-Euroopan maiden tavoin Suomessa on elatustukijärjestelmä, joka viimekädessä turvaa elatuksen niille lapsille, jotka eivät saa sitä toiselta vanhemmaltaan (esim. Skinner \& Davidson 2009). Elatustuki voi vaikuttaa keskeisesti perheiden toimeentuloon, sillä lapset saavat todennäköisemmin elatusta niissä maissa, joissa on elatustukijärjestelmä (Hakovirta \& Jokela 2018). Lapsen elatus yhteiskunnallisena kysymyksenä kytkeytyykin siihen, miten taloudellinen vastuu jakautuu vanhempien välillä ja toisaalta siihen, miten se jakautuu yhteiskunnan ja vanhempien välillä (Corden 1999; Skinner \& Davidson 2009). Lapsen elatus yhdistyy siten keskeiseen perhepoliittiseen kysymykseen julkisen ja yksityisen välisestä jaosta lapsiperheiden toimeentulon turvaamisessa (Millar 1996).
Vaikka lapsen elatuksen kysymykset koskettavat konkreettisella tavalla sekä vanhempien että heidän lastensa jokapäiväistä toimeentuloa, elatusjärjestelmää ei ole Suomessa kovin paljon tutkittu, eikä sitä ole vakiintuneesti liitetty sosiaaliturvan tai köyhyystutkimuksen perinteisiin siitä huolimatta, että aiheesta on käyty keskustelua jo lähes sadan vuoden ajan (Rantalaiho 2009). Aikaisempaa tutkimustietoa on siis melko vähän siitä, miten ja missä määrin muualla asuvat vanhemmat osallistuvat lapsen elatukseen ja toisaalta siitä, miten elatustuki turvaa lapsen elatusta. Suomessa tutkimus on myös lähes täysin jättänyt huomioimatta sen, miten maksettu elatusapu vaikuttaa elatusvelvolliseen ja hänen kotitaloutensa toimeentuloon. Kansainvälisissä tutkimuksissa on nimittäin havaittu, että elatusavun maksaminen lisää köyhyyttä sekä elatusapua maksavien isien kotitalouksissa (Hakovirta ym. 2019b) että näissä kotitalouksissa asuvien lasten keskuudessa (Cuesta \& Meyer 2018).

Suomessa vanhemmat usein jakavat lapsen huollon eron jälkeen, mutta lapsen elatus- ja asumisjärjestelyt ovat silti hyvin sukupuolittuneita (Kuronen 2003; Rantalaiho 2009). Eron jälkeen valtaosa lapsista jää asumaan äidin kanssa (Lapsen elatus ja huolto 2019), jolloin isät ovat useammin elatusvelvollisia vanhempia ja maksavat elatusapua.Tässä artikkelissa tarkastelemme lapsen elatusta sekä yksinhuoltajaäitien että elatusvelvollisten isien toimeentulon näkökulmasta. ${ }^{1}$ Tuotamme tietoa siitä, miten yksityinen ja julkinen elatus jakautuu yksinhuoltajaäitien kotitalouksissa ja miten elatusapu ja -tuki kohdentuvat vanhempien tulotason mukaan. Lisäksi tutkimme, miten lap- 
sen elatus vaikuttaa yksinhuoltajaäitien ja elatusapua maksavien isien tuloköyhyyteen. Aineistona käytämme Suomen tulonjakotilaston palveluaineistoa vuodelta 2013.

\section{ELATUSJÄRJESTELMÄ JA PERHEIDEN TOIMEENTULO}

Perhesuhteisiin liittyviä oikeuksia ja velvollisuuksia ohjataan yhteiskunnan taholta ja myös eron jälkeinen vanhemmuus on yhteiskunnallisesti vahvasti säädeltyä (Kuronen 2003; MacLean \& Eekelaar 1997; Millar \& Warman 1996). Tämä koskee myös lapsen elatusta. Lapsen oikeus elatukseen molemmilta vanhemmiltaan on yksi lapsen perusoikeuksista, joka on turvattu sekäYK:n lapsen oikeuksien sopimuksella että kansallisella lainsäädännöllä (Gottberg 1995).

Elatusjärjestelmän taustalla voi olla monia erilaisia periaatteita ja tavoitteita, jotka ohjaavat sitä, miten elatusvastuuta jaetaan vanhempien välillä ja miten lapsen elatus tulisi järjestää (esim. Millar 1996; Corden 1999). Monessa maassa lapsen toisen vanhemman elatusvastuun vahvistaminen on ollut yksi tärkeä tavoite ja keskeinen osa elatusjärjestelmien kehitystä. Osassa maista lapsen toisen vanhemman elatusvastuun vahvistamisella on myös haettu ratkaisua yksinhuoltajakotitaloudessa asuvien lasten toimeentulon turvaamiseen ja köyhyyden vähentämiseen. (Skinner ym. 2012.) Myös Suomessa lapsen toisen vanhemman taloudellisen vastuun vahvistaminen ja yksinhuoltajakotitalouksissa asuvien lasten toimeentulon turvaaminen oli keskeinen yhteiskunnallinen tavoite elatusjärjes- telmän syntyvaiheessa. Nykyisin elatusjärjestelmällä ei ole suoraa köyhyyden vähentämisen tavoitetta. Suomessa perhelainsäädäntö korostaa ennemminkin jaettua vanhemmuutta eli sitä, että huolenpitovastuuta lapsesta jaetaan vanhempien välillä myös eron jälkeen. (Hakovirta \& Hiilamo 2012.) Jaetun vanhemmuuden ideaali on osa laajempaa keskustelua isyydestä ja sen muutoksesta (Rantalaiho 2003) sekä siitä, että lapsen edun mukaista on, että vanhemman ja lapsen välinen suhde jatkuu myös vanhempien eron jälkeen (KurkiSuonio 1999). Tätä on korostettu myös uudessa lapsenhuoltolaissa (ks. Koulun puheenvuoro tässä numerossa).

Suomessa molemmilla vanhemmilla on siis ensisijainen vastuu lapsen elatuksesta, mutta lapselle voidaan maksaa julkista elatustukea, mikäli lapsen muualla asuva vanhempi ei kykene huolehtimaan lapsen elatuksesta tai laiminlyö elatusavun maksamisen tai jos lapsella ei ole toista elatusvelvollista vanhempaa $^{2}$ (Gottberg 1995; Hakovirta \& Hiilamo 2012). Elatustukijärjestelmä paitsi turvaa kaikille lapsille elatusta myös ohjaa sitä, missä määrin vanhemman tulisi osallistua lapsen elatukseen ja missä tilanteissa on sallittua, että vanhempi ei maksa elatusapua (Ahola 2016; Sarasoja \& Rantala 2015). Kelan tilastojen mukaan elatustukea sai vuonna 2017 Suomessa noin kymmenen prosenttia kaikista alaikäisistä lapsista (Kela 2018). Elina Aholan (2016) mukaan vuonna 2010 noin puolelle lapsilisän yksinhuoltajakorotusta saavalle yksinhuoltajalle oli maksettu elatustukea. Kaikista yksinhuoltajaperheistä 29 prosenttia sai elatustukea ainakin osittain siitä syystä, että elatusvelvollinen oli laiminlyönyt elatusavun maksamisen (mt.). Nämä 
luvut kertovat yhteiskunnan keskeisestä roolista lapsen elatuksen turvaajana Suomessa.

Lainsäädäntö ja laajemmin elatusjärjestelmä asettavat puitteet sille, miten vanhemmat voivat järjestää lapsen elatuksen, ja minkä tasoista elatusapua elatusvelvolliselta vanhemmalta voidaan odottaa. Suomessa lapsen huolto- ja elatusneuvotteluissa vanhemmilla on keskeinen rooli, sillä he voivat sopia lapsen elatuksesta keskenään tai sosiaalilautakunta voi vahvistaa vanhempien välisen sopimuksen. Tuomioistuin ratkaisee lapsen elatuksen niissä tapauksissa, joissa vanhemmat eivät pääse sopimukseen. Lähtökohtana elatusavun määräytymiselle on kuitenkin aina lapsen elatuksen tarve, joka jaetaan vanhempien kesken. Vanhempien toimeentuloa suojataan elatusjärjestelmässä siten, että elatusavun määräytymisessä tulisi huomioida molempien vanhempien elatuskyky, kuten tulot ja muut resurssit. (Hakovirta \& Hiilamo 2012.) Jaetun vanhemmuuden ideaaliin sisältyy ajatus siitä, että lapsen elatuksen taso ei saisi olla niin korkea, että se häiritsee isän ja lapsen yhteydenpitoa, jolloin esimerkiksi lapsen kanssa vietetty aika tulisi myös huomioida elatusavun määräytymisessä (Bergman \& Hobson 2002; Eydal \& Kröger 2010; Hakovirta \& Hiilamo 2012).

Onkin haastavaa määritellä, mikä elatuksen taso olisi oikeudenmukainen lapsen ja vanhempien näkökulmasta ja miten elatusavun määrä lasketaan niin, että se olisi riittävä lapsen elatukseksi, mutta vastaisi samalla myös elatusvelvollisen vanhemman elatuskykyä. Käytännössä elatusavun määrä voi vaihdella paljonkin eri perheiden välillä, sillä elatusapua koskevassa lainsäädännössä määritellään vain yleisesti ne tekijät, jotka vaikuttavat elatusavun määräytymiseen. Toisaalta yksilökohtainen harkinta turvaa sen, että elatusavun määräytymisessä huomioidaan perheiden erilaiset elämäntilanteet. Elatusjärjestelmän ongelmaksi voi kuitenkin muodostua se, että samassa tilanteessa olevia perheitä ei välttämättä kohdella samalla tavoin.

Elatusjärjestelmän vaikutus vanhempien toimeentuloon riippuu siis monista eri tekijöistä, kuten siitä, miten vanhempien elatuskykyä arvioidaan ja miten elatusjärjestelmät huomioivat perheiden erilaiset elämäntilanteet ja niiden muutokset (esim. Cancian ym. 2011). Elatusjärjestelmän piirteiden lisäksi perheiden toimeentulon kannalta on keskeistä arvioida elatusjärjestelmän lopputulosta: kuinka moni yksinhuoltaja saa lapselleen elatusta ja kuinka paljon elatusvelvolliset maksavat elatusapua. Nämä tekijät taas voivat myös olla keskeisesti yhteydessä vanhempien toimeentuloon. Seuraavaksi tarkastelemme aikaisemman tutkimuksen valossa lapsen elatuksen ja vanhempien toimeentulon yhteyttä sekä yksinhuoltajaäitien että elatusapua maksavien isien näkökulmasta.

\section{Äidit ja lapsen elatus}

Lapsen kanssa asuvat äidit huolehtivat lapsen taloudellisesta huolenpidosta sekä omilla palkkatuloillaan että sosiaalipoliittisilla tulonsiirroilla ja toisen vanhemman maksamalla elatusavulla. Suomessa noin 80 prosenttia yksinhuoltajaäideistä sai vuonna 2013 elatusapua tai elatustukea. (Hakovirta \& Jokela 2018.) Vaikka Suomessa suurin 
osa yksinhuoltajaäideistä saa elatusapua lapsen toiselta vanhemmalta ja lapsen elatus on viime kädessä turvattu elatustuella, on elatusavun ja elatustuen osuus silti melko pieni tarkasteltaessa yksinhuoltajäitien käytettävissä olevia tuloja. Yksinhuoltajakotitalouksien kokonaistuloista elatusapu ja elatustuki muodostavat vain noin 10 prosenttia (Ahola 2016; Hakovirta \& Jokela 2018). Tämä johtuu osaltaan siitä, että saatu elatusapu on Suomessa tasoltaan selvästi matalampi kuin esimerkiksi Saksassa, Espanjassa, Isossa-Britanniassa tai Yhdysvalloissa ja että Suomessa yksinhuoltajaäitien palkkatulojen osuus on melko korkea (Hakovirta \& Jokela 2018). Tasoltaan Suomessa yksinhuoltajaäitien saama ja elatusvelvollisten maksaman elatusavun määrä on rinnastettavissa elatustukeen (Rissanen \& Aaltonen 2018; Hakovirta \& Jokela 2018).

Kansainvälisistä tutkimuksista tiedämme, että elatusapua saa todennäköisemmin korkeasti koulutetut ja työssäkäyvät yksinhuoltajaäidit (Cuesta \& Meyer 2012). Sen sijaan pienituloiset yksinhuoltajaperheet, jotka eniten olisivat elatusavun tarpeessa, eivät Suomessa aina sitä saa, ja joutuvat turvautumaan elatustukeen (Hakovirta \& Jokela 2018). Elatustuen saantia Suomessa selittävät Elina Aholan (2016) tutkimuksen mukaan äidin nuori ikä, matala sosioekonominen asema ja pitkä yksinhuoltajuushistoria sekä perheen suuri lapsimäärä ja pienemmät tulot.

Köyhyyden vähentäminen on yksi keskeisimmistä hyvinvointivaltioiden tehtävistä ja monessa maassa myös yksi elatusapujärjestelmän tavoitteista (Skinner ym. 2007). Lapsen elatuksen on ai- kaisemmissa tutkimuksissa todettu jossain määrin vähentävän lapsiköyhyyttä (esim. Hakovirta 2011; Hakovirta ym. 2019a). Elatusapu vähentää köyhyyttä vähiten maissa, joissa yksinhuoltajista vain pieni osa saa elatusapua. Niiden yksinhuoltajien keskuudessa, jotka saavat elatusapua tai -tukea, elatuksen köyhyyttä vähentävä vaikutus on luonnollisesti korkeampi. Näin on myös Suomessa. Hakovirran ym. (2019a) tulosten mukaan elatusapu ja elatustuki yhdessä vähensivät yksinhuoltajaäitien köyhyyttä 14 prosenttiyksikköä vuonna 2013. Toisaalta Suomessa ongelmia voi syntyä silloin, kun yksinhuoltajat saavat sekä elatusapua (tai elatustukea) että toimeentulotukea. Toimeentulotukea myönnettäessä huomioidaan kaikki kotitalouden saamat tulot, jolloin myös lapselle maksettava elatusapu tai elatustuki lasketaan tuloksi. Tämä tarkoittaa sitä, että toimeentulotukea saavan yksinhuoltajaperheen tulot eivät nouse toimeentulotukinormin yläpuolelle, vaikka toinen vanhempi maksaisikin elatusapua. Elatusapu tai -tuki eivät siten vähennä köyhyyttä toimeentulotukea saavissa yksinhuoltajakotitalouksissa eivätkä hyödytä toimeentulotuen varassa eläviä pienituloisia yksinhuoltajia. (mt.)

Tiedämme siis jonkin verran siitä, miten elatusapu ja -tuki yhdessä vaikuttavat yksinhuoltajien toimeentuloon Suomessa. Vähemmän on tietoa yksinhuoltajakotitalouksien saaman elatuksen jakautumisesta julkisen ja yksityisen elatuksen välillä, ja siitä, miten eri elatuksen muodot vaikuttavat yksinhuoltajaäitien toimeentuloon ja köyhyyteen. Tuloluokkien välisiä eroja elatusavun saannissa on selitetty avioliittojen homogamisuudella eli sillä, 
että liittoja solmivat hyvin samanlaisista sosioekonomisista taustoista lähtöisin olevat henkilöt. Se, että pienituloinen yksinhuoltajaperhe ei saa elatusta tai elatuksen taso on matala voi siten johtua siitä, että lapsen kanssa erillään asuva vanhempi on myös itse pienituloinen eikä pysty huolehtimaan lapsen elatuksesta. (Skinner ym. 2017; Skinner \& Main 2013.) Tämän perusteella voimme olettaa, että Suomessa pienituloiset yksinhuoltajaperheet ovat todennäköisemmin julkisen elatustuen piirissä, kun taas suurempituloiset yksinhuoltajat saavat pienituloisia todennäköisemmin elatusapua. Lapsen elatuksen määrä riippuukin keskeisesti myös elatusvelvollisesta vanhemmasta.

\section{Isät ja lapsen elatus}

Vaikka vanhempien ero ja lapsen elatuksen järjestäminen voivat vaikuttaa molempien osapuolten toimeentuloon, isien eron jälkeisestä toimeentulosta tiedetään huomattavasti vähemmän kuin yksinhuoltajaäideistä. Monet tutkimukset ovat nostaneet esille, että huono-osaisemmat pariskunnat eroavat muita pareja herkemmin (esim. Jalovaara 2013) ja ero voi sysätä miehet syrjäytymisen polulle (esim. Kiiski 2011; Koskela 2012). Isossa-Britanniassa ja Yhdysvalloissa on havaittu, että lapsesta erillään asuvat isät ovat lapsen kanssa asuvia isiä nuorempia ja heillä on lapsen kanssa asuvia isï heikompi taloudellinen asema (Poole ym. 2013; Bradshaw ym. 1999; Dermott 2016; Sorensen 1997). Isien sosioekonomisesta asemasta ei ole kuitenkaan yhtenäistä kuvaa. Yhtenä syynä tälle voidaan pitää sitä, että isistä on haastavaa saada kansallisesti edustavaa tietoa (esim. Poole ym. 2013; Stykes ym. 2013). Suomalaista vertailu- kohtaa ei ole saatavilla, sillä Suomessa tietoa lapsestaan erossa asuvista isistä ei ole, eikä muiden maiden tietoja voida suoraan siirtää koskemaan Suomea.

Isän perhetilanne ja elinolosuhteet vaikuttavat kuitenkin keskeisesti isän kykyyn huolehtia lapsen elatuksesta ja niiden tarkastelu on tärkeää lapsen elatukseen liittyvissä kysymyksissä. Isän tuloilla, koulutuksella ja työmarkkina-asemalla on vaikutus isän elatuskykyyn. Isät esimerkiksi maksavat sitä enemmän elatusapua mitä suuremmat tulot heillä on. (Risssanen \& Aaltonen 2018; Smock \& Manning 1997; Fletcher Needles 1989.) Mia Hakovirran ym. (2019b) tutkimuksen mukaan isien maksaman elatusavun taso on Suomessa melko matala verrattuna esimerkiksi Iso-Britanniaan ja Yhdysvaltoihin. Suomessa elatusapua määrättäessä huomioidaan molempien vanhempien elatuskyky ja resurssit, jotka voivat vaikuttaa maksetun elatusavun tasoon. (mt.). Maiden välisiä vertailuja haittaa kuitenkin se, että elatusapua koskevat tiedot ovat peräisin erilaisista lähteistä.

Elatusavun merkitystä elatusvelvollisen toimeentuloon voi tarkastella myös nykyisen perhetilanteen näkökulmasta. Jos isällä on uusia lapsia uudessa kotitaloudessa, hänellä voi olla vähemmän taloudellisia resursseja tukea kotitalouden ulkopuolella asuvia lapsia (Cuesta \& Meyer 2018). Uusi kumppani taas voi tuoda lisää taloudellisia resursseja kotitalouteen, mutta toisaalta myös lisätä kotitalouden tarpeita (Meyer \& Skinner 2016).Yksinasuvilla isillä ei puolestaan ole käytössään samoja skaalaetuja kuin parisuhteessa elävillä isillä, mikä puolestaan voi vaikuttaa maksetun elatusavun tasoon. 
Isien perhetilanne vaikuttaa toisaalta myös siihen, mikä vaikutus elatusavun maksamisella on elatusvelvollisen uudelle perheelle. Etenkin pienituloisten isien aseman elatusapu voi tehdä haastavaksi. Pienituloisilla isillä elatusavun maksutaakka voi muodostua suureksi, sillä tutkimuksissa on havaittu, että elatusavun osuus tuloista on tyypillisesti suurin juuri pienituloisilla isillä ( $\mathrm{Ha}-$ kovirta ym. 2019b; ks. myös Stirling \& Aldrich 2008; Huang ym. 2005). Aiemmissa kansainvälisissä ja kansainvälisesti vertailevissa tutkimuksissa on myös havaittu elatusavun maksamisen nostavan isien köyhyysastetta 1-7 prosenttiyksikköä (Hakovirta ym. 2019b; Cancian ym. 2011; Cancian \& Meyer 2004; Bartfeld 2000; Meyer 1998). Nämä tutkimukset ovatkin kysyneet, kuinka hyvin elatusjärjestelmä onnistuu ottamaan huomioon pienituloiset elatusvelvolliset isät sekä heidän perhetilanteensa.

\section{Aineisto Ja MENETELmät}

Tässä artikkelissa selvitämme, miten vastuu lapsen elatuksesta jakautuu yksinhuoltajaperheissä yksityisen ja julkisen elatuksen välillä sekä mikä merkitys lapsen elatuksella on perheiden toimeentulolle. Ensimmäinen tutkimuskysymyksemme on, kuinka suuri osa yksinhuoltajaäideistä saa elatusta ja eroaako elatuksen lähde erituloisissa perheissä. Toiseksi kysymme, kuinka paljon isät maksavat elatusapua ja onko elatuksen tasossa eroja erituloisissa kotitalouksissa. Kolmanneksi kysymme, miten lapsen elatus vaikuttaa köyhyyteen yksinhuoltajaäitien kotitalouksissa ja lisääkö elatusavun maksaminen taas köyhyyttä isien kotitalouksissa. Aineistona käytämme Suomen tulonjakoti- laston palveluaineistoa vuodelta 2013. Palveluaineisto on tulonjakotilastosta tutkimustarkoitukseen tuotettu aineisto, jonka kohdeperusjoukkona ovat yksityiset kotitaloudet. Aineistosta saadaan tietoa tulonjaon eri osista, kuten palkkatuloista, tulonsiirroista ja veroista. Aineisto kerätään vuosittain ja sen otoskoko on noin 10000 kotitaloutta ja noin 25000 henkilöä. Tiedot aineistoon on kerätty puhelinhaastatteluin sekä hallinnollisista rekistereistä ja tilastoista, kuten verohallinnon verotietokannasta ja Kelan rekisteristä.

Tämän tutkimuksen kohdejoukkona ovat yksinhuoltajaäitien sekä elatusvelvollisten eli elatusapua maksavien isien kotitaloudet. Aineistosta on mahdollista erottaa kaikki yksinhuoltajakotitaloudet, mutta siitä ei ole mahdollista identifioida kaikkia lapsesta erillään asuvia isiä. Siten analysoimme artikkelissa vain niitä elatusvelvollisia isiä, jotka ovat maksaneet elatusapua (vrt. Hakovirta 2019b).

Yksinhuoltajaäitien kotitalouksiksi määrittelimme ne kotitaloudet, joissa on yksinhuoltaja(äiti) ja vähintään yksi alle 18-vuotias lapsi $(n=248)$. Lesket on jätetty pois analyyseista. Elatusvelvollisiksi isiksi laskimme miehet, jotka ovat maksaneet elatusapua. Olemme jakaneet isät kolmeen eri ryhmään: yksinasuviin, lapsettomiin pariskuntiin sekä pariskuntiin, joilla on lapsia $(n=128)$. Muunlaiset isäkotitaloudet, kuten yksinhuoltajat, olemme jättäneet analyyseista pois vähäisten havaintomäärien vuoksi $(n=6)$. Aineiston yksinhuoltajaäitien ja isien taustapiirteet on raportoitu liitteessä 1. 
Elatusapu on kotitalouksien välinen tulonsiirto, joka voi perustua vanhempien väliseen keskinäiseen sopimukseen tai sosiaalilautakunnan tai tuomioistuimen vahvistamaan elatusapusopimukseen. Tulosten tulkinnassa tulee huomioida, että tulonjakotilastosta saatavat tiedot elatusavusta eroavat tietolähteiltään. Tieto maksetusta elatusavusta on saatu verohallinnon rekisteristä, jos elatusvelvollinen vanhempi on tehnyt elatusvelvollisuusvähennyksen. Elatusvelvollisuusvähennyksen voi tehdä vahvistetun elatusapusopimuksen mukaisesti maksetun elatusavun perusteella. Kotitalouksien saama elatusapu on haastattelutieto. Tieto kotitalouden vuoden aikana saamasta elatustuesta on saatu Kelan rekisteristä. On myös hyvä huomioida, että elatusapu ja -tuki ovat tulonjakotilastossa kotitalouden vuoden aikana saama tai maksama määrä kokonaisuudessaan kaikista lapsista, ja elatusapua ja -tukea on voitu saada tai maksaa vuoden jokaisena kuukautena tai vain joinakin kuukausina.

Empiirisen osuuden tulokset jakautuvat kahteen osaan, joista ensimmäisessä tutkimme lapsen elatuksen kohdentumista tulotason mukaan. Toisessa osassa tarkastelemme, miten lapsen elatus vaikuttaa vanhempien kotitalouksien köyhyyteen. Tulovertailua varten muodostimme yksinhuoltajaäitien tuloista ja isien tuloista viisi tuloluokkaa. Tuloina käytimme kotitalouden käytettävissä olevia ekvivalentteja tuloja ennen kuin elatusapua tai elatustukea on saatu tai elatusapua on maksettu (vrt. Hakovirta \& Jokela 2018; Skinner ym. 2017; Skin- ner \& Main 2013). Tulonjakotilastossa kotitalouden käytettävissä olevat tulot on muodostettu laskemalla yhteen kotitalouden jäsenten palkka-, yrittäjä- ja omaisuustulot sekä saadut tulonsiirrot, jonka jälkeen on vähennetty kotitalouden maksamat tulonsiirrot. Köyhyyttä kuvaamme suhteellisen tulometodin avulla, jossa köyhiksi määrittelimme ne kotitaloudet, joiden käytettävissä olevat ekvivalentit tulot ovat alle 60 prosenttia väestön mediaanitulosta. Kulutusyksikkönä käytimme modifioitua OECDkulutusyksikköä. Köyhyystarkastelussa laskimme, miten köyhyysasteet muuttuvat absoluuttisesti ja suhteellisesti, kun kotitalous on joko saanut elatusta tai maksanut elatusapua.

\section{LAPSEN ELATUKSEN TASO JA KOHDENTUMINEN}

Lapsen elatus yksinhuoltajaäitien kotitalouksissa

Yksinhuoltajaäidit voivat saada lapsen elatusta joko lapsen toiselta vanhemmalta elatusapuna tai yhteiskunnan maksamana elatustukena. Taulukossa 1 on esitetty, kuinka moni yksinhuoltajakotitalous saa elatusapua ja -tukea, ja mistä saatu elatus muodostuu. Vuonna 2013 lähes 80 prosenttia yksinhuoltajakotitalouksista oli saanut joko elatusapua tai elatustukea. Hieman yli puolet yksinhuoltajaäideistä oli saanut elatusapua ja lähes 40 prosenttia elatustukea. Elatusapua saatiin määrällisesti enemmän kuin elatustukea. 
Taulukko 1. Elatusapua- tai tukea saavien yksinhuoltajaäitien osuus (\%) ja saadun elatuksen määrä (€/v) elatustyypin mukaan kotitalouksissa vuonna 2013.

\begin{tabular}{llllll}
\hline $\begin{array}{l}\text { Kaikki } \\
\text { yksinhuoltaja- } \\
\text { äidit, N. }\end{array}$ & $\begin{array}{l}\text { Saa elatusapua tai } \\
\text { elatustukea, n. }\end{array}$ & $\begin{array}{l}\text { Osuus kaikista } \\
\text { yksinhuoltaja- } \\
\text { äideistä, \%. }\end{array}$ & $\begin{array}{l}\text { Saadun } \\
\text { elatuksen } \\
\text { ka., } € .\end{array}$ & $\begin{array}{l}\text { Saadun } \\
\text { elatuksen } \\
\text { md., } € .\end{array}$ & sd., $€$. \\
\hline 248 & 197 & 79,4 & 3270 & 2581 & 2262
\end{tabular}

Yksinhuoltajaäitien saama elatus elatustyypin mukaan $^{a}$

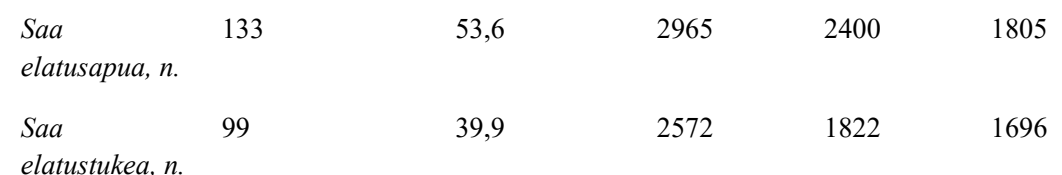

Lähde: Suomen tulonjakotilaston palveluaineisto 2013, kirjoittajien laskelmat.

Huom: Kotitalouden painokerroin on huomioitu analyyseissä.

${ }^{a}$ Yksinhuoltajaäitien kotitalouksista 14,1 prosenttia oli saanut sekä elatusapua että elatustukea. Kotitalous on voinut saada vuoden aikana elatusapua sekä elatustukea esimerkiksi silloin, kun kotitalouden lapsista osa saa elatusapua ja osa elatustukea tai jos lapsi saa elatusapua täydentävää elatustukea tai jos elatustukea ja/tai elatusapua on saatu vain osan vuotta. Näiden kotitalouksien saaman elatuksen taso oli kaikista korkein, keskiarvolla mitattuna 3045,2 euroa vuodessa.

Taulukko 2. Elatusapua- tai tukea saavien yksinhuoltajaäitien osuus (\%) ja saadun elatuksen määrä (€/v) tuloviidennesten ja elatustyypin mukaan kotitalouksissavuonna vuonna 2013.

\begin{tabular}{|c|c|c|c|c|c|c|}
\hline & & Alin & 2 & 3 & 4 & Ylin \\
\hline Saa elatusapua tai elatustukea, $\%$. & & 84,0 & 81,0 & 84,4 & 81,5 & 68,4 \\
\hline \multirow[t]{2}{*}{ Saadun elatuksen määrä, $€$. } & ka. & 3912 & 2618 & 2925 & 3112 & 3872 \\
\hline & md. & 3000 & 2364 & 2000 & 2300 & 3600 \\
\hline
\end{tabular}

Yksinhuoltajaäitien saama elatus elatustyypin mukaan

Saa elatusapua, \%.

Saadun elatusavun määrä, $€$.

Saa elatustukea, \%

Saadun elatustuen määrä, $\epsilon$.

$\begin{array}{cccccc} & 48,0 & 47,6 & 57,8 & 63,0 & 50,9 \\ \text { ka. } & 3158 & 2184 & 2849 & 2973 & 3481 \\ \text { md } & 3000 & 2400 & 2400 & 2160 & 3600 \\ & 58 & 45,2 & 42,2 & 31,4 & 26,3 \\ \text { ka. } & 3200 & 2427 & 2298 & 2092 & 2545 \\ \text { md. } & 1822 & 1822 & 1822 & 1822 & 2820\end{array}$

13, kirjoittajien laskelmat.

Lähde: Suomen tulonjakotilaston palveluaineisto 2013, kirjoittajien laskelmat.

Huom: Tuloviidennekset on muodostettu kotitalouden ekvivalenteista käytettävissä olevista tuloista ennen elatusapua ja -tukea. Kotitalouden painokerroin on huomioitu analyyseissä. 
Taulukossa 2 esitetään elatusapua tai -tukea saavien yksinhuoltajaäitien osuus ja saadun elatuksen määrä tuloviidennesten mukaan. Elatuksen saannissa ei ollut suuria eroja tuloviidennesten välillä. Ylimpään tuloviidennekseen kuuluvista yksinhuoltajaäideistä pienin osuus sai elatusta. Kuitenkin, kun tarkastelemme elatusapua ja elatustukea erikseen, tuloluokkien välillä on havaittavissa enemmän eroja.Alimpaan ja toiseksi alimpaan tuloluokkaan kuuluvat yksinhuoltajakotitaloudet saivat muita tuloluokkia harvemmin elatusapua. Elatusapua saaneiden yksinhuoltajakotitalouksien osuus oli suurin toiseksi ylimmällä tuloluokalla, ja elatusavun taso oli korkein ylimmässä tuloluokassa.

Taulukossa 2 esitetään myös elatuksen jakautuminen yksityiseen ja julkiseen elatukseen tuloluokkien mukaan. Lapsen elatuksen muodostuminen elatus- tuesta on yleisempää pienituloisemmissa yksinhuoltajakotitalouksissa. Ero alimman ja ylimmän tuloluokan välillä elatustuen saannissa oli noin 31 prosenttiyksikköä. Tulokset siis osoittavat, että suurempituloisissa kotitalouksissa lapsen elatus muodostuu elatusavusta pienituloisia kotitalouksia yleisemmin ja etenkin pienituloisilla yksinhuoltajilla elatustuki toimii lapsen elatuksen turvaajana.

\section{Lapsen elatus isien kotitalouksissa}

Taulukossa 3 on esitetty isien maksaman elatusavun taso ja suhteellinen osuus käytettävissä olevista tuloista tuloviidenneksittäin. Isien maksama elatusapu oli vuonna 2013 keskimäärin 2937 euroa vuodessa. Mitä suuremmat elatusvelvollisen isän kotitalouden tulot olivat, sitä enemmän elatusapua maksettiin.

Taulukko 3. Isien maksama elatusapu (€/v) ja osuus (\%) tuloista kotitalouden tuloviidennesten mukaan vuonna 2013.

\begin{tabular}{|c|c|c|c|c|c|c|}
\hline & & Alin & 2 & 3 & 4 & Ylin \\
\hline \multirow{2}{*}{$\begin{array}{l}\text { Maksetun elatusavun } \\
\text { määrä, €. }\end{array}$} & ka. & 2470 & 2345 & 2893 & 3344 & 3820 \\
\hline & md. & 2040 & 1952 & 3087 & 2640 & 3360 \\
\hline $\begin{array}{l}\text { Elatusavun osuus isän } \\
\text { tuloista ,\%. }\end{array}$ & & 10,6 & 6,4 & 7,5 & 6,2 & 4,3 \\
\hline
\end{tabular}

Maksetun elatusavun $\mathrm{ka}$.

yhteensä, $€$.

Maksetun elatusavun md.

yhteensä, $\epsilon$.

$s d ., €$.

Lähde: Suomen tulonjakotilaston palveluaineisto 2013, kirjoittajien laskelmat

Huom: Tuloviidennekset on muodostettu kotitalouden ekvivalenteista käytettävissä olevista tuloista ennen elatusapua.

Kotitalouden painokerroin on huomioitu analyyseissä.

a Keskiarvoisen maksetun elatusavun suhde isän käytettävissä olevien tulojen keskiarvoon 
Isän toimeentulon kannalta on merkitystä sillä, kuinka suuren osuuden elatusapu muodostaa tuloista. Elatusavun osuus tuloista oli suurin kaikista pienituloisimmilla isillä. Elatusapu muodosti alimpaan tuloviidennekseen kuuluvien isien kotitalouksien tuloista noin 10 prosenttia, kun taas ylimmällä tuloviidenneksellä noin 4 prosenttia. Ero alimman ja ylimmän tuloluokan välillä oli siis noin 6 prosenttiyksikköä. Tämä kertoo siitä, että pienituloiset isät maksavat suuremman osan tuloistaan elatusapuina kuin suurituloisemmat isät.

\section{LAPSEN ELATUKSEN VAIKUTUS KÖYHYYTEEN}

Elatusapu voi vaikuttaa kotitalouden köyhyyteen monella eri tavalla (ks. Bradshaw 2006), mutta tarkastelemme seuraavaksi sitä, miten elatusapu vähentää köyhyyttä elatusapua saavissa yksin- huoltajakotitalouksissa, jossa lapsi asuu. Toiseksi tarkastelemme miten elatusvelvollisen maksama elatusapu vaikuttaa köyhyyteen elatusvelvollisen omassa kotitaloudessa.

Elatusapua tai -tukea saaneista yksinhuoltajaäitien kotitalouksista lähes puolella tulot alittivat köyhyysrajan ennen elatusavun ja -tuen saamista (taulukko 4). Elatusapu ja -tuki vähensivät köyhien yksinhuoltajakotitalouksien määrää 21 prosenttiyksikköön niissä kotitalouksissa, jotka saivat elatusta. Suhteellisesti köyhyys väheni noin 42 prosenttia elatusavun ja elatustuen saannin jälkeen. Kun tarkastellaan erikseen julkista ja yksityistä elatusta, elatusapu vähensi köyhyyttä 37 prosenttia elatusapua saaneiden yksinhuoltajien kotitalouksissa, kun taas elatustukea saaneissa kotitalouksissa elatustuki vähensi köyhyyttä vajaan neljänneksen.

Taulukko 4. Köyhyysaste (60\% mediaanitulosta) ennen ja jälkeen elatusavun ja -tuen yksinhuoltajaäitien kotitalouksissa vuonna 2013.

\begin{tabular}{lllll}
\hline & $\begin{array}{l}\text { Köyhyysaste } \\
\text { ennen } \\
\text { elatusta }\end{array}$ & $\begin{array}{l}\text { Köyhyysaste } \\
\text { elatuksen } \\
\text { jälkeen }\end{array}$ & $\begin{array}{l}\text { Absoluuttine } \\
\text { n vähennys, } \\
\% \text {-yksikköä }\end{array}$ & $\begin{array}{l}\text { Suhteellinen } \\
\text { vähennys, \% }\end{array}$ \\
\hline $\begin{array}{l}\text { Kaikki yksinhuoltajaäidit } \\
\text { Elatuapua tai -tukea } \\
\text { saaneet yksinhuoltajaäidit }\end{array}$ & 48,7 & 34,6 & 14,1 & 28,9 \\
$\begin{array}{l}\text { Vaikutus köyhyyteen elatustyypin mukaan }{ }^{a} \\
\begin{array}{l}\text { Elatusapua saaneet } \\
\text { yksinhuoltajaäidit }\end{array}\end{array}$ & 28,1 & 21,0 & 42,7 \\
$\begin{array}{l}\text { Elatustukea saaneet } \\
\text { yksinhuoltajä̈idit }\end{array}$ & 54,0 & 25,3 & 14,9 & 37,0 \\
\hline
\end{tabular}

Lähde: Suomen tulonjakotilaston palveluaineisto 2013, kirjoittajien laskelmat.

${ }^{a}$ Elatusavun vaikutus köyhyyteen on laskettu elatusapua saaneilta yksinhuoltajaäideiltä ja elatustuen vaikutus

köyhyyteen on laskettu elatustukea saaneilta yksinhuoltajaäideiltä. 
Taulukko 5. Köyhyysaste (60 \% mediaanitulosta) ennen ja jälkeen elatusavun elatusvelvollisten isien kotitalouksissa kotitalouden rakenteen mukaan vuonna 2013.

\begin{tabular}{lllll}
\hline & $\begin{array}{l}\text { Köyhyysaste } \\
\text { ennen } \\
\text { elatusavun } \\
\text { maksamista }\end{array}$ & $\begin{array}{l}\text { Köyhyysaste } \\
\text { elatusavun } \\
\text { maksamisen } \\
\text { jälkeen }\end{array}$ & $\begin{array}{l}\text { Absoluuttinen } \\
\text { lisäys, \% } \\
\text { yksikköä }\end{array}$ & $\begin{array}{l}\text { Suhteellinen } \\
\text { lisäys, \% }\end{array}$ \\
\hline Yksinasuvat isät & 8,2 & 18,6 & 10,4 & 126,8 \\
$\begin{array}{l}\text { Puolison kanssa } \\
\text { asuvat isät }\end{array}$ & 0,0 & 0,0 & 0,0 & 0,0 \\
$\begin{array}{l}\text { Puolison ja lasten } \\
\text { kanssa asuvat isät }\end{array}$ & 6,6 & 6,6 & 0,0 & 0,0 \\
Kaikki isät & 5,8 & 9,8 & 4,0 & 68,9 \\
\hline
\end{tabular}

Lähde: Suomen tulonjakotilaston palveluaineisto 2013, kirjoittajien laskelmat.

Isien perhemuoto on tärkeässä asemassa analysoitaessa elatusavun maksamisen vaikutuksia köyhyyteen, sillä kotitalouden muut huollettavat vaikuttavat isän kykyyn maksaa elatusapua ja isän maksama elatusapu voi vaikuttaa paitsi isän omaan myös samassa kotitaloudessa asuvien perheenjäsenten toimeentuloon (Cuesta \& Meyer 2018; Hakovirta ym. 2019b). Toisaalta taas myös yksinasuvien asema elatusavun maksajina voi olla heikko, sillä köyhyys paikantuu Suomessa erityisesti yksinasuvien ihmisten kotitalouksiin (Mukkila ym. 2017). Kotitalouden rakenteen mukaisesti tarkasteltuna köyhyys olikin yleisintä yksinasuvien elatusvelvollisten isien kotitalouksissa (18,6 prosenttia). Puolison ja lasten kanssa asuvien isien kotitaloudessa köyhyysaste oli 6,6 prosenttia. Vain puolison kanssa asuvien isien kotitaloudet eivät jääneet köyhyysrajan alapuolelle. (Taulukko 5.)

Miten lapsen elatus sitten vaikuttaa isien köyhyyteen? Taulukossa 5 on kuvattu köyhyysasteet ennen ja jälkeen makse- tun elatusavun. Elatusavun maksamisen jälkeen isien kotitalouksista köyhyysrajan alitti neljä prosenttiyksikköä enemmän kuin ennen elatusavun maksamista. Elatusavun maksaminen nosti vain yksinasuvien isien köyhyysastetta ja köyhien kotitalouksien osuus kasvoi noin 10 prosenttiyksiköllä. Elatusavun maksaminen ei lisännyt köyhyyttä puolison tai puolison ja lasten kanssa asuvien isien kotitalouksissa. Vaikeimmassa tilanteessa ovat siten yksinasuvat elatusapua maksavat isät.

\section{JOHTOPÄÄTÖKSET}

Lapsiperheiden toimeentulokysymykset ja lapsen elatus ovat olleet yhteiskuntapoliittisia kysymyksiä kautta historian ja entistä ajankohtaisemmaksi teeman tekee se, että lapsiperheiden köyhyys on Suomessa kasvanut (Karvonen \& Salmi 2016). Myös avo- ja avioerot ovat yleisiä ja lapsen elatukseen liittyvät kysymykset koskevat entistä suurempaa osaa suomalaisista lapsiperheistä. Tässä 
artikkelissa tarkastelimme lapsen elatusjärjestelmää Suomessa köyhyys- ja hyvinvointitutkimuksen viitekehyksessä. Analysoimme, miten yksityinen ja julkinen elatus jakautuivat yksinhuoltajaäitien kotitalouksissa ja mikä rooli lapsen toisen vanhemman maksamalla elatusavulla ja toisaalta julkisella elatustuella on yksinhuoltajaperheiden toimeentuloon. Lisäksi analysoimme, miten yksinhuoltajaäitien saama elatusapu tai elatustuki vähensivät köyhyyttä.

Aikaisemmat tutkimukset ovat tuoneet esille, että Suomessa suurin osa yksinhuoltajaäideistä saa elatusta ja elatustukijärjestelmällä on keskeinen rooli lapsen elatuksen turvaajana (Hakovirta \& Jokela 2018; Ahola 2016). Aiempaa tutkimustietoa ei ole kuitenkaan ollut siitä, missä määrin muualla asuvat vanhemmat osallistuvat lapsen elatukseen ja milloin taas yhteiskunta on ottanut vastuuta lapsen elatuksesta elatustuen muodossa. Tulosten mukaan elatustuki turvaa lapsen elatusta kaikissa tuloluokissa, mutta elatustuen rooli on keskeisin pienituloisissa kotitalouksissa. Myös saadun elatusavun taso oli matalampi alemmissa tuloluokissa. Tämä voi johtua osaltaan liittojen homogamiasta. Pientuloisilla yksinhuoltajaäideillä lapsen toinen vanhempi on voinut olla pienituloinen ja äidit joutuvat turvautumaan elatustukeen.

Köyhyystarkastelu osoitti, että elatusavulla ja elatustuella on tärkeä rooli yksinhuoltajaäitien köyhyyden vähentämisessä, ja että erityisesti elatusapu vähentää köyhyyttä tehokkaasti. Yksinhuoltajaperheiden toimeentuloa voitaisiin siis parantaa niin, että kaikille lapsille turvataan elatusta myös lapsen toiselta vanhemmalta. Elatusapu ei voi kuitenkaan toimia pääasiallisena ratkaisuna yksinhuoltajaperheissä asuvien lasten toimeentulon turvaamisessa, sillä elatusapua maksavilla vanhemmilla on vain rajallinen elatuskyky ja myös heidän toimeentulonsa on huomioitava. Suomessa köyhyyden vähentämistä ei olekaan pidetty elatusjärjestelmän suorana tavoitteena. Oleellista olisi huomioida, miten lapsen elatus toimii muun sosiaaliturvajärjestelmän kanssa (Skinner ym. 2012). Vaikka on tärkeää turvata lapsen elatus lapsen molemmilta vanhemmilta, kaikista pienituloisimpien yksinhuoltajaperheiden asemaa voidaan mahdollisesti parantaa tekemällä muutoksia siihen, miten kotitalouden saama elatus huomioidaan toimeentulotuen määräytymisessä (Hakovirta ym. 2019a).

Elatuslainsäädäntö pyrkii mahdollistamaan molemmille vanhemmille taloudellisesti turvatun vanhemmuussuhteen jatkumisen parisuhteen päättymisestä huolimatta. Suomessa on kuitenkin vähän tutkimusta siitä, kuinka isän maksama elatusapu vaikuttaa hänen toimeentuloonsa. Kansainvälisissä tutkimuksissa on todettu, että maksettu elatusapu saattaa synnyttää köyhyyttä myös elatusvelvollisten ja heidän uusien perheidensä keskuudessa (Cuesta \& Meyer 2018; Hakovirta ym. 2019b). Tämän vuoksi analysoimme artikkelissa elatusjärjestelmää myös isän näkökulmasta. Tulostemme mukaan isän maksama elatusapu oli luonnollisesti matalampi pienituloisissa kotitalouksissa, koska elatusavun tasoa määrättäessä huomioidaan isien tulot. Siitä huolimatta pienituloiset isät maksavat suuremman osan tuloistaan elatusapuina kuin suurituloiset isät, jolloin elatusavun maksamisella on suurempi mer- 
kitys kotitalouden toimeentulolle (ks. myös Hakovirta ym. 2019b; Stirling \& Aldrich 2008; Huang ym. 2005). Köyhyysanalyysi toikin esille sen, että isän maksama elatusapu voi aiheuttaa maksajalle toimeentulovaikeuksia. Taloudellisesti huonoimmassa asemassa olivat yksinasuvat isät, joiden köyhyysaste nousi elatusavun maksamisen johdosta.

Elatusavun maksamisen vaikutus isien köyhyyteen herättää kysymyksen, kuinka hyvin elatusapumääräykset vastaavat Suomessa vanhemman elatuskykyä. Yksi Suomen elatusjärjestelmään liitetty ongelma on ollut, että elatusapusopimusten muuttamista on arvosteltu hyvin kankeaksi elatusavun maksajan näkökulmasta (Sarasoja \& Rantala 2015, 12), mikä voi vaikeuttaa etenkin pienituloisten vanhempien selviytymistä elatusapumaksuista. Aihe on tärkeä myös lapsen elatuksen turvaamisen kannalta. Sopivat elatusapumääräykset, jotka vastaavat elatusvelvollisen vanhemman elatuskykyä, nostavat todennäköisyyttä, että vanhempi osallistuu lapsen taloudelliseen huolenpitoon (Huang ym. 2005).

Suomessa tutkimusta lapsen elatuksesta vanhempien eron jälkeen rajoittaa jossain määrin edustavien aineistojen puute ja tilastointikäytänteiden rajallisuus. Suomessa ei ole kerätty väestötasolla edustavaa kyselytutkimusaineistoa eroperheistä ${ }^{3}$, eikä laajoissa kansallisissa kyselytutkimuksissa tyypillisesti kysytä kotitalouden ulkopuolella asuvista lapsista. Suomesta ei siis toistaiseksi ole saatavilla valtakunnallisesti tai väestöryhmittäin kattavaa tietoa lasten asumis- tai elatusjärjestelyistä vanhempien eron jälkeen. Suomalaisilla tutkimusaineistoilla ei päästä kovin hyvin käsiksi eroperheiden arkeen ja erilaiset kotitalouksien väliset taloudelliset kytkökset jäävät niissä osin näkymättömiin $(\mathrm{Ok}$ konen 2014).

Myös tämän artikkelin tuloksia tulee tulkita varoen. Ensinnäkin isien kohdalla tulosten yleistettävyyden kannalta ongelmana ovat pienet havaintomäärät ja se, että emme voi esittää tietoa siitä, kuinka suuri osa lapsen muualla asuvista vanhemmista maksaa elatusapua, kuinka suurella osalla vanhemmista on elatusapuvähennykseen oikeuttava sopimus lapsen elatuksesta ja miten vanhempien taustapiirteet, kuten taloudellinen asema on yhteydessä näihin tekijöihin. Toiseksi analysoimme vain elatusavun maksajia. Elatusavun saanti tai maksaminen eivät kerro kaikkea siitä, miten lapsen elatus jakautuu vanhempien välillä. Jotkut vanhemmat sopivat lapsen elatuksesta keskenään ja jakavat lapsesta aiheutuvia kuluja muuten kuin elatusavulla. Ulkomaisissa tutkimuksissa on myös havaittu, että isät maksavat usein elatusavun ohella muita lapsesta aiheutuvia kuluja erityisesti silloin, jos tapaamiset lapsen kanssa ovat säännöllisiä (Nepomnyaschy 2007). Tutkimustietoa tulisi siten huomattavasti lisätä kotitalouksien välisistä perhesuhteista ja lapsen eron jälkeisen elatuksen vaikutuksesta perheiden toimeentuloon.

\section{Viitteet}

1 Yksinhuoltajuudella emme viittaa lapsen huoltojärjestelyyn vaan kotitalouden rakenteeseen, joka muodostuu yhdestä vanhemmasta (äidistä) ja lapsista. Elatusvelvollisilla isillä tarkoitamme miehiä, jotka ovat maksaneet elatusapua. Jatkossa kutsumme artikkelissa elatusvelvollisia isiä lyhyemmin isiksi.

2 Toisen vanhempansa menettäneen lapsen elatuksen turvaa lapseneläke. 
3 Kela toteuttaa vuosina 2019-2020 yhteistyössä Turun ja Tampereen yliopistojen kanssa hankkeen Lasten vuoroasuminen ja sosiaaliturva, jossa tarkastellaan lapsen asumisjärjestelyjä eron jälkeen. Hankkeessa kerätään valtakunnallinen kysely eroperheistä. https://tietokayttoon.fi/hankkeet/ hanke-esittely/-/asset_publisher/lastenvuoroasuminen-ja-sosiaaliturva

\section{KirjallisuUs}

Ahola, Elina (2016) Elatustuen merkitys yksinhuoltajaperheiden toimeentulolle. Teoksessa Anita Haataja, Ilpo Airio, Miia Saarikallio-Torp \& Maria Valaste (toim.) Laulu 573566 perheestä. Lapsiperheet ja perhepolitiikka 2000-luvulla. Helsinki: Kela, 288-306.

Airio, Ilpo (2010) Avioero suomalaiseen tapaan. Teoksessa Ulla Hämäläinen \& Olli Kangas (toim.) Perhepiirissä. Helsinki: Kansaneläkelaitos.

Bartfeld, Judi (2000) Child support and the postdivorce economic well-being of mothers, fathers, and children. Demography 37 (2), 203-213. https://doi. org/10.2307/2648122

Bergman, Helena \& Hobson, Barbara (2002) Compulsory fatherhood: The coding of fatherhood in the Swedish welfare state. Teoksessa Barbara Hobson (toim.) Making Men into Fathers. Men, Masculinities and the Social Politics of Fatherhood. Cambridge: Cambridge University Press, 92-124. https://doi. org/10.1017/CBO9780511489440.005

Bradshaw, Jonathan (2006) Child support and child poverty. Journal of Social Security 14 (3), 199-208.

Bradshaw, Jonathan \& Stimson, Caroline \& Skinner, Christine \& Williams, Julie (1999) Absent fathers? London: Routledge. https://doi. org/10.4324/9780203252376

Cancian, Maria \& Meyer, Daniel (2004) Fathers of children receiving welfare: Can they provide more child support? Social Service Review 78 (2), 179-206. https://doi.org/10.1086/382766

Cancian, Maria \& Meyer, Daniel \& Han,
Eunhee (2011) Child support: Responsible fatherhood and the quid pro quo. American Academy of Political and Social Science 636 (1), 140-162. https:// doi.org/10.1177/0002716210393640

Corden, Anne (1999) Making child maintenance regimes work. London: Family Policy Studies Centre.

Cuesta, Laura \& Meyer, Daniel (2018) Child poverty and child support policy: a comparative analysis of Colombia and the United States. Children and Youth Services Review 93 (1), 143 153. https://doi.org/10.1016/j.childyouth.2018.07.013

Cuesta, Laura \& Meyer, Daniel (2012) Child support receipt: Does context matter? A comparative analysis of $\mathrm{Co}-$ lombia and the United States. Children and Youth Services Review 34 (9), 1876-1883. https://doi.org/10.1016/j. childyouth.2012.05.023

Dermott, Esther (2016) Non-resident fathers in the UK: living standards and social support. Journal of Poverty and Social Justice 24 (2), 113-125. https://doi.org/ 10.1332/175982716X14605378167871

Eydal, Gudny Björk \& Kröger, Teppo (2010) Nordic family policies: constructing contexts for social work with families. Teoksessa Hannele Forsbeg \& Teppo Kröger (toim.) Social work and child welfare politics. Through Nordic lenses. Bristol: Policy Press.

Fletcher Needles, Cynthia (1989) A comparison of incomes and expenditures of male-headed households paying child support and female-headed households receiving child support. Family Relations 38 (4), 412-417. https://doi. org $/ 10.2307 / 585746$

Gottberg, Eva (1995) Perhe, elatus ja sosiaaliturva. Tutkimus yksityisen ja julkisen elatusvastuun rajoista, rakenteesta ja toimivuudesta.Yksityisoikeuden sarja A: 80 . Turun yliopisto: Oikeustieteellinen tiedekunta.

Hakovirta, Mia (2011) Child maintenance and child poverty: A comparative analysis. Journal of Poverty and Social Justice 19 (3), 249-262. https://doi. org/10.1332/175982711X596991

Hakovirta, Mia \& Skinner, Christine \& Hiilamo, Heikki \& Jokela, Merita (2019a) 
Child poverty, child maintenance and interactions with social assistance benefits among lone parent families: a comparative analysis. Journal of Social Policy, 1-21. First view. https://doi.org/10.1017/ S0047279419000151

Hakovirta, Mia \& Meyer, Daniel \& Skinner, Christine (2019b) Does paying child support impoverish fathers in the US, Finland, and the UK? Children and Youth Services Review 106, 1-10. https://doi. org/10.1016/j.childyouth.2019.104485

Hakovirta, Mia \& Jokela, Merita (2018) Contribution of child maintenance to lone mothers' income in five welfare states. Journal of European Social Policy 29 (2), 257-272. https://doi. org/10.1177/0958928717754295

Hakovirta, Mia \& Hiilamo, Heikki (2012) Children's rights and parent's responsibilitites. Child maintenance policies in Finland. European Journal of Social Security 14 (4), 286-303. https:// doi.0.1177/138826271201400405

Huang, Chien \& Mincy, Ronald \& Garfinkel, Irwin (2005) Child support obligations and low-income fathers. Journal of Marriage and Family 67 (5), 12131225. https://doi.org/10.1111/j.17413737.2005.00211.x

Jalovaara, Marika (2013) Socioeconomic resources and the dissolution of cohabitations and marriages. European Journal of Population 29 (2), 167-193. https://doi. org/10.1007/s10680-012-9280-3

Karvonen, Sakari \& Salmi, Minna (2016) Lapsiköyhyys Suomessa 2010-luvulla. Helsinki:Terveyden ja hyvinvoinninlaitos.

Kiiski, Jouko (2011) Suomalainen avioero 2000-luvun alussa. Miksi avioliitto puretaan, miten ero koetaan ja miten siitä selviydytään? Publications of the University of Eastern Finland. Dissertations in Education, Humanities, and Theology No 15. Joensuu: University of Eastern Finland.

Kela (2018) Kelan lapsiperhe-etuustilasto 2017. Sosiaaliturva 2018. Helsinki: Kela.

Koskela, Jari (2012) Avioero suomalaisen miehen kokemana. Ero ja erosta toipuminen prosessina. Publications of the University of Eastern Finland. Dissertations in Social Sciences and Business Studies., no 46. Kuopio: University of Eastern Finland. Kurki-Suonio, Kirsti (1999) Äidin hoivasta yhteishuoltoon - lapsen edun muuttuvat oikeudelliset tulkinnat. Helsinki: Helsingin yliopisto.

Kuronen, Marjo (2003) Eronnut perhe? Teoksessa Hannele Forsberg \& Ritva Nätkin (toim.). Perhe murroksessa. Helsinki: Gaudeamus.

Lapsen elatus ja huolto (2019) Helsinki:Terveyden ja hyvinvoinnin laitos.

Maclean, Mavis \& Eekelaar, John (1997) The parental obligation. A study of parenthood across households. Oxford: Hart Publishing.

Meyer, Daniel (1998) The effect of child support on the economic status of nonresident fathers. Teoksessa Irwin Garfinkel, Sarah MacLanahan, Daniel Meyer \& Judy Seltzer (toim.) Fathers Under Fire. The Revolution in Child Support Enforcement. USA: Russell Sage Foundation, 67-93.

Meyer, Daniel \& Skinner, Christine (2016) Privileging biological or residential relationships: family policy on obligations to children in 12 countries. Families, Relationships, and Societies 5 (1), 79-95. https://doi.org/10.1332/20467431 4X14128653771806

Millar, Jane (1996) Family obligations and social policy: The case of child support. Policy Studies 17 (3), 181-193.

Millar, Jane \& Warman, Andrea (1996) Family obligations in Europe. London: Family Policy Studies Centre. https://doi. org/10.1080/01442879608423706

Mortelmans, Dimitri \& Defever, Christine (2017) Income trajectories of lone parents after divorce:A view with Belgian register data. Teoksessa Laura Bernardi \& Dimitri Mortelmans (toim.) Lone Parenthood in the Life Course. Life Course Research and Social Policies. Cham: Springer. https:// doi.org/10.1007/978-3-319-63295-7 9

Mukkila,Susanna \& Ilmakunnas, Ilari \& Moisio, Pasi \& Saikkonen, Paula (2017) Perusturvan riittävyys ja köyhyys 2017. Helsinki: Terveyden ja hyvinvoinninlaitos. http:// urn.fi/URN:ISBN:978-952-302-938-5. Luettu 8.10.2019.

Nepomnyaschy, Lenna (2007) Child support and father-child contact: Testing reciprocal pathways. Demography 44 (1), 93-112. https://doi.org/10.1353/dem.2007.0008 Okkonen Kaisa-Mari (2014) Erolasten arki 
ei välity tilastoihin. Hyvinvointikatsaus $1 / 2014$. https://www.stat.fi/artikkelit/2014/art_2014-02-26_007.html Luettu 8.5.2019.

Poole, Eloise \& Speight, Svetlana \& O'Brien, Margaret \& Conolly, Sara \& Aldrich, Matthew (2016) Who are nonresident fathers? A British socio-demographic profile. Journal of Social Policy 45 (2), 223-250. https://doi.org/10.1017/ S0047279415000653

Rantalaiho, Minna (2003) Pohjoismaisen isyyspolitiikan isyyskuva. Teoksessa Hannele Forsberg \& Ritva Nätkin (toim.) Perhe murroksessa. Helsinki: Gaudeamus, 202-229

Rantalaiho, Minna (2009) Suomalainen yksinhuoltajuus ja yhteiskuntamuutos: Aviottomasta äitiydestä jaettuun vanhemmuuteen. Teoksessa Katja Forssén, Anita Haataja \& Mia Hakovirta (toim.) Yksinhuoltajuus Suomessa. Helsinki: Väestöliitto, 19-45.

Rissanen, Antti \& Aaltonen, Mikko (2018) What influences the size of child maintenance payments? A register-based study of maintenance payments in Finland. International Journal of Social Welfare 28 (2), 128-137. https://doi.org/10.1111/ ijsw.12325

Sarasoja, Laura \& Rantala, Kati (2015) Ero lapsiperheessä: Elatus, sopiminen ja vuoroasuminen. Katsauksia 2/2015. Helsingin yliopisto: Kriminologian ja oikeuspolitiikan instituutti.

Skinner, Christine \& Cook, Kay \& Sinclair, Sarah (2017) The potential of child support to reduce lone mother poverty: Comparing population survey data in Australia and the UK. Journal of Poverty and Social Justice 25 (1), 79-94. https://doi.org/10.1 332/175982717X14860543256937

Skinner, Christine \& Main, Gill (2013) The contribution of child maintenance payments to the income packages of lone mothers. Journal of Poverty and Social Justice 21 (1), 47-60. https://doi. org/10.1332/175982712X657109

Skinner, Christine \& Hakovirta, Mia \& Davidson, Jacqueline (2012) A comparative analysis of child maintenance schemes in five countries. European Journal of Social Security 14 (4), 330-347. https://doi. org/10.1177/138826271201400407
Skinner, Christine \& Davidson, Jacqueline (2009) Recent trends in child maintenance schemes in 14 countries. International Journal of Law, Policy and the Family 23 (1), 25-52. https://doi. org/10.1093/lawfam/ebn017

Skinner, Christine \& Bradshaw, Jonathan \& Davidson, Jacqueline (2007) Child support policy: An international perspective. Leeds: Department for Work and Pensions.

Smock, Pamela \& Manning, Wendy (1997) Nonresident parents' characteristics and child support. Journal of Marriage and Family 59 (4), 798-808. https://doi. org/10.2307/353783

Sorensen, Elaine (1997) A national profile of nonresident fathers and their ability to pay child support. Journal of Marriage and the Family 59 (4), 785-797. https:// doi.org/10.2307/353782

Stirling, Kate \& Aldrich, Tom (2008) Child support: Who bears the burden? Family Relations 57 (3), 376-386. https://doi. org/10.1111/j.1741-3729.2008.00507.x

Stykes, Bart \& Manning, Wendy \& Brown, Susan (2013) Nonresident fathers and formal child support: Evidence from the CPS, the NSFG, and the SIPP. Demographic Research 29 (46), 1299-1330. https:// doi.org/10.4054/DemRes.2013.29.46

SVT (2019) Lapseton aviopari on yhä yleisin perhetyyppi. Perheet vuosikatsaus 2017. http://www.stat.fi/til/perh/2017/02/ perh_2017_02_2018-12-05_kat_001_ fi.html. Luettu 8.5.2019.

Uunk, Wilfred (2004) The Economic Consequences of Divorce for Women in the European Union: The Impact of Welfare State Arrangements European Journal of Population 20 (3), 251-285. https://doi. org/10.1007/s10680-004-1694-0 


\section{Liitteet}

Liite 1. Yksinhuoltajaäitien ja elatusapua maksaneiden isien taustapiirteet aineistossa

\begin{tabular}{|c|c|c|c|c|}
\hline \multirow[b]{2}{*}{ Ikä } & \multicolumn{2}{|c|}{ Yksinhuoltajaäidit } & \multicolumn{2}{|c|}{ Elatusapua maksaneet isät } \\
\hline & $\mathrm{n}$. & $\%$. & $\mathrm{n}$. & $\%$. \\
\hline alle 35 & 54 & 21,8 & 12 & 9,4 \\
\hline $35-44$ & 82 & 33,1 & 47 & 36,7 \\
\hline $45-54$ & 104 & 41,9 & 56 & 43,8 \\
\hline 55 tai yli & 8 & 3,2 & 13 & 10,2 \\
\hline \multicolumn{5}{|l|}{ Lasten $1 \mathrm{~km}$ kotitaloudessa } \\
\hline 0 & - & - & 83 & 64,8 \\
\hline 1 & 147 & 59,3 & 18 & 14,1 \\
\hline 2 & 75 & 30,2 & 19 & 14,8 \\
\hline $3+$ & 26 & 10,5 & 8 & 6,3 \\
\hline \multicolumn{5}{|c|}{ Kotitalouden nuorimman lapsen ikä (v.) } \\
\hline alle 3 & 27 & 10,9 & 19 & 42,2 \\
\hline $3-6$ & 56 & 22,6 & 12 & 26,7 \\
\hline $7-12$ & 72 & 29,0 & 6 & 13,3 \\
\hline $13-17$ & 93 & 37,5 & 8 & 17,8 \\
\hline \multicolumn{5}{|l|}{ Koulutus } \\
\hline Enintään perusaste & 29 & 11,7 & 22 & 17,2 \\
\hline Keskiasteen tutkinto & 160 & 64,5 & 80 & 62,5 \\
\hline Korkeakoulu-tutkinto & 59 & 23,8 & 26 & 20,3 \\
\hline \multicolumn{5}{|l|}{ Sosioekonominen asema } \\
\hline Yrittäjä & 23 & 9,3 & 27 & 21,1 \\
\hline Ylempi toimihenkilö & 44 & 17,7 & 28 & 21,9 \\
\hline Alempi toimihenkilö & 89 & 35,9 & 17 & 13,3 \\
\hline Työntekijä & 29 & 11,69 & 38 & 29,7 \\
\hline Pitkäaikaistyötön & 19 & 7,66 & 11 & 8,6 \\
\hline Muu & 44 & 17,7 & 7 & 5,5 \\
\hline \multicolumn{5}{|l|}{ Toiminta joulukuussa } \\
\hline Kokoaikatyössä & 157 & 67,3 & 104 & 81,6 \\
\hline Osa-aikatyössä & 18 & 7,3 & 3 & 2,3 \\
\hline Työtön & 23 & 9,3 & 12 & 9,4 \\
\hline Muu & 40 & 16,1 & 9 & 7,0 \\
\hline
\end{tabular}

Lähde: Suomen tulonjakotilaston palveluaineisto 2013, kirjoittajien laskelmat. 